\title{
Monitoring (Dis)Agreement in Dyadic Parent-Child Reports on Health-Related Quality of Life Assessment
}

Rita Vaičekauskaitè ${ }^{1}$, Jūratė Grubliauskiené ${ }^{\text {, Jurgita Babarskiené }}{ }^{3}$, Ričardas Krikštolaitis ${ }^{4}$

1 Klaipeda University, Faculty of Health Science, Herkaus Manto g. 84, Klaipeda, LT-92294, Lithuania, rita.vaicekauskaite@ku.lt

2 Klaipeda University, Faculty of Health Science, Herkaus Manto g. 84, Klaipeda, LT-92294, Lithuania, jurate.grubliauskiene@ku.lt

3 LCC International University, Department of Psychology, Kretingos g. 36, Klaipeda, LT-92307, Lithuania, jbabarskiene@lcc.lt

4 Vytautas Magnus University, Department of Mathematics and Statistics, Vileikos g. 8, LT-44404, Kaunas, ricardas.krikstolaitis@vdu.lt

Annotation. Research on children's quality of life is increasingly focused on the new design when the questionnaires are filled out not only by parents but also by children. However, there is a problem in how to evaluate the disagreement in dyadic children's and parents' reports. Our research was carried out with 1564 children/adolescents and parents who completed the KIDSCREEN-52 questionnaire in Lithuanian. Our paper calls into question the monitoring of dyadic disagreements as lacking conceptual perspective and addresses self-rated health as shedding systemic insights into the topic.

Keywords: self-rated health, quality of life, children/adolescents, dyadic assessment, proxyreports.

\section{Introduction}

The abundance and recognition of research about children's quality of life have been growing over the last two decades. This is related to the development of quality of life research instruments and to the changing societal attitudes towards childhood. In the practice of the quality of life research, mainly questionnaires about a child's quality of life were completed by parents. Following the longstanding critique, new instruments 
have been developed which enable self-reporting by children and adolescents. In addition, more studies have revealed that children from 8 years old can evaluate their own health, relating it to a wide scope of social factors such as friends, the environment, sports, sleeping, good food, etc. (Knighting et al., 2011; Kostmann, \& Nilsson, 2012). Moreover, children younger than 8 years old are able to use rating scales as well as common response terms, can understand, and interpret the underlying concepts. Therefore, we should recognize children's ability to assess their own health-related quality of life (HRQoL) (Cremeens et al., 2006).

From the point of view of many researchers, the one-sided attitude of the parents will never replace the opinion of the child. In fact, individual self-assessment is the core element in the quality of life idea, which represents a person's physical, social, economic, and psychological satisfaction in life. HRQoL relates the health (which cannot be restricted to illness or disability) with a person's well-being and is also assessed by self-reports. It follows that parent's proxy reports alone contradict the subjective nature of the quality of life concept, and the child's own assessment is also needed.

In the dyadic HRQoL research design when the questionnaires are filled out not only by parents, but also by children, there is a problem in how to analyze the disagreement in dyadic children's and parent's reports, especially when examining them with different questionnaires. Recognizing these constraints, the KIDSCREEN questionnaire applies the same versions for both children/adolescents and parents. However, in any kind of questionnaire, we face many disagreements in the assessments of the quality of life between children and parents. But due to the lack of conceptuality, we cannot say that some differences are better or worse than others (Upton et al., 2008), or having greater reliability (Matza et al., 2004).

Some studies link discrepancies between children's and parent's assessment to a lack of monitoring of reasoning and attitudes. Applying qualitative research, it has been observed that the differences between the answers of parents and children arise from the fact that they either reason differently or interpret things differently (Davis et al., 2007). Some studies assert that children, in general, provide more extreme answers than their parents (Dey et al., 2013). Other studies relate parent's higher scores to the fact that children may be under reporting (Havermans et al., 2006). However, Upton et al. (2008) assert that parent-child disagreements are part of a wider generic problem, indicating a lack of parental knowledge about children's experiences and beliefs.

Studies mainly relate parent-child agreement with the child's disability, although no stable patterns have been observed. For instance, agreement on physical functioning is likely to be higher for children who have rheumatic disease than for children with diabetes, where parent-child agreement on physical activities is lower (Varni, 2002). Nevertheless, in a study with Cystic fibrosis, parent's and children's agreement in the areas that relate to observable physical well-being was partly confirmed (Havermans et al., 2006). Furthermore, children with attention deficit disorders rated their HRQoL significantly 
better than their parents in the areas of behavior, self-esteem, mental health, and family cohesion, and significantly poorer for physical function (Klassen et al., 2006).

Different studies usually show that children's illness is a significant factor for parent-child congruence on HRQoL assessment, although we do not have a conceptual explanation for that. For instance, in the period of six months after a newly diagnosed chronic disease of a child, researchers observe more agreement between parent's and children's reports (Qadeer \& Ferro, 2018). It might be related to increased parental involvement around issues of health due to the child having a diagnosed health problem, so that their understanding of the child's well-being is heightened (Upton et al., 2008). However, such explanations have never been conceptually investigated (Eiser \& Morse, 2001), so it remains challenging to explain special cases when children with illness evaluate their HRQoL better than their parents. Havermans and colleagues (2006) assume that children adapt to their situation and rate the impact of illness as less severe. Parents, however, may report the impact of the illness as being higher because of their own distress or because of the information they have received regarding the illness, its prognosis and development, and the information that has not yet been disclosed to the child. Children, on the other hand, may rate their HRQoL higher because they do not want to admit how much their health condition affects them (Dey et al., 2013).

Breidablik et al. (2009) assert that self-rated health (SRH) enables to go beyond a restricted medical health status. However, SRH of adolescents has not been studied extensively (Page et al., 2009). One longitudinal study shows that $59 \%$ of the adolescent's SRH remained unchanged over the 4 -year observation period. Being diagnosed with a medical condition or specific mental or somatic health symptoms was of less importance for later SRH (Breidablik et al., 2009). Later in life, poor self-rated health has been consistently found to be a reliable predictor for mortality, often exceeding the predictive power of other "objective" medical factors (Falconer, \& Quesnel-Vallée, 2017). Assessment of SRH depends merely on the social factors (Bombak, 2013; Rezende et al., 2017) that are integral with the quality of life. To the best of our knowledge, many studies underestimate the impact of self-rated health on the quality of life assessment.

The current study provides insights into dyadic HRQoL assessment using the KIDSCREEN-52 questionnaire, which enables for child self- and parent-proxy reports of HRQoL. Developed by a consortium of researchers in Europe, the KIDSCREEN is a generic measure of HRQoL that includes children/adolescents and parent-proxy 52 or 27-item versions (Ravens-Sieberer et al., 2007; 2014). KIDSCREEN has solved the problem of lack of parallel content when different instruments for parents and children are used to report HRQoL. KIDSCREEN allows us to extend knowledge of the factors influencing child-parent agreement in HRQL assessment.

Information about variables contributing to parent-child agreement levels remain limited and, therefore, we need to systematically investigate variables that impact the levels of parent-child agreement (Upton et al., 2008). The objective of the current study 
is to investigate (dis)agreement between child/adolescents and parent proxy-reports of HRQoL. The research questions are as follows: whether parents rate their child's/ adolescent's HRQoL better or poorer than their child/adolescent and in which dimensions; whether (dis)agreement is related to the self-rated health factor and demographic characteristics of a child; and how the factor of illness is related with self-rated health.

Our study results show that the dimensions of parents' and children/adolescent's quality of life assessments differ mostly when either parents or children assess self-rated health as good, and mostly overlap when they rate it as poor. On the basis of self-rated health assessment, we can distinguish four categories of children and parents' dyads, which in further studies could be used for creating specific educational strategies for improving children's/adolescent's health-related quality of life.

\section{Methodology}

\section{Study design}

The KIDSCREEN-52 questionnaire is completed separately by both the children/ adolescents themselves and their parents. Their questions were identical, except for small changes in the wording to direct the question to the appropriate respondent (e.g., "Do you ..." vs. "Does your child ..."). Thus, the parent version corresponds in its scale structure to the version for children and adolescents. It consists of similar items but asks the parents to respond by indicating how they assume their children feel or think. To obtain data not only from children but also from parents of the same family, the questionnaires were coded in pairs, i.e. families were given child and parent questionnaires with unique matching codes. In Lithuania research using the KIDSCREEN-52 questionnaire was not conducted before.

The study design was approved of the bio-ethical council of the Health Science Faculty, Klaipeda University in Lithuania. The survey was conducted in secondary schools in Lithuania from October 1, 2015, to February 29, 2016. For this study, schools were selected at random using the random number generator built into the SPSS software. Based on the data provided by the Statistics Department of Lithuania, on January 1, 2015, there were 1,195 schools in Lithuania. 11 Lithuanian schools, which constitute approximately $1 \%$, were selected for the investigation. In the selected schools, 2,500 questionnaires were distributed to students in grades 2-12, out of which 1763 questionnaires were filled out and returned, with $70.52 \%$ of the children's questionnaires that have been distributed returned. 2,500 questionnaires were disseminated to the parents of the children participating in the survey, out of which 1564 or $62.5 \%$ were returned. There were 1564 participant pairs (i.e., when both the child, and one of their parents completed the questionnaire). 
The principal investigator contacted the school's administration to explain the aim and scope of the research. Participation in the study was voluntary and anonymous. The research sample is representative and consists of children from 8 to 18 years old and their parents from Lithuania. The children's ages were selected in compliance with the recommendations provided by KIDSCREEN study (Ravens-Sieberer et al., 2006).

Children completed anonymous paper questionnaires in the classroom. The aim and the procedures of the study were explained before the questionnaires were completed. Completing the questionnaires took approximately 30 minutes. Parents filled out anonymous paper questionnaires at home that were brought to them by their children in a sealed envelope. The parents and children in all families participating in the study were encouraged to complete their questionnaires independently to maintain the confidentiality of all respondents. All procedures were carried out following the data protection requirements.

\section{Data analysis}

Data analysis was performed using version 21 of IBM's SPSS statistics software (Statistical Package for Social Sciences) and Microsoft Excel. To check for data entry mistakes, frequencies of the responses were calculated. Survey data was compiled into a united database, using participant identification based on the following key characteristics: municipality code, school code, and family code. The use of a unified family code allowed us to identify the families who participated in the study, distinguish the parent from a child and perform family data analysis. KIDSCREEN items use 5-point answer categories to assess either the frequency (never-seldom-quite often-very often-always) or intensity (not at all-slightly-moderately-very-extremely) of the responses. The internal consistency of the KIDSCREEN-52 was determined by calculating the Cronbach's a coefficient. To assess relations between different dimensions the Mann-Whitney U test, Chi-square test, Cramer's $V$ correlation coefficient were used. The decision about statistically significant differences was accepted at a significance level of $p=.05$.

\section{Demographic indicators}

1,564 children were randomly selected in 11 secondary schools in Lithuania, yielding a total of 1,564 families where surveys were completed by both the child and his/her parents. Their age ranged from 7-18 years old, with $43.5 \%$ of children from the 12-15-year-old age group and 29.5\% from the 16-18-year-old age group. In terms of gender, $51.1 \%$ of

the participants were girls and $48.9 \%$ were boys (see Table 1). $38.4 \%$ of parents had high education, slightly more than one fifth of them (21.7\%) had university education, $16.8 \%$ were graduates of vocational schools. Regarding the marital status, $72.6 \%$ were married or cohabited, almost one fifth (17.9\%) of the parents were divorced, 5.5\% were not married and did not cohabit and $4.0 \%$ were widows and widowers (see Table 1 ). 
Table 1

Demographic Characteristics

\begin{tabular}{lcll}
\hline \multicolumn{1}{c}{ Parents } & & \multicolumn{1}{c}{$\begin{array}{c}\text { Children/ } \\
\text { adolescents }\end{array}$} \\
\hline Total: 1564 & & & $\begin{array}{l}\text { Total: } 1564 \\
\text { AGE }\end{array}$ \\
EDUCATION & & & $27.0 \%$ \\
Elementary & $4.1 \%$ & $7-11$ years & $43.5 \%$ \\
High school & $38.4 \%$ & $12-15$ years & $29.5 \%$ \\
Unfinished high school & $9.4 \%$ & $16-18$ years & \\
Vocational school & $16.8 \%$ & GENDER & \\
$\begin{array}{l}\text { Non-university higher education } \\
\text { degree }\end{array}$ & $9.6 \%$ & Boys & $48.9 \%$ \\
University degree & $21.7 \%$ & Girls & $51.1 \%$ \\
MARITAL STATUS & & & \\
Married / cohabiting & $72.6 \%$ & & \\
Divorced & $17.9 \%$ & & \\
Unmarried/do not live together & $5.5 \%$ & & \\
Widows & $4.0 \%$ & & \\
\hline
\end{tabular}

\section{Findings}

In the original English version and in the Lithuanian version, KIDSCREEN-52 consists of 10 dimensions: physical well-being, psychological well-being, mood and emotions, self-perceptions, autonomy, family life, peers and social support, school environment, social acceptance (bullying) and financial resources (Grubliauskienė, 2019; Ravens-Sieberer et al., 2006). In the current study, however, we reorganized 10 dimensions into five thematic dimensions referring to the 5-dimensional structure (KIDSCREEN 27) as follows:

- social and emotional (psychological) well-being;

- physical activity;

- school environment and relationship;

- family;

- independence (autonomy) and friendship.

The internal validity of the thematic dimensions (henceforth - dimensions) in the questionnaire was assessed by the Cronbach's alpha coefficient and varied between .799-.896 for children and .709-.873 for parents. Four categories of dyadic self-rated health (SRH) assessment were created as follows: good-good, good-poor, poor-good, and poorpoor, respectively referring to children/adolescent's and parent's reports. They are based 
on the question "In general, how would you say your health is?" for children/adolescent's self-reported health assessment. The corresponding question for parent's proxy-reported health assessment was "In general, how does your child rate his/her health?".

In order to identify the relationship between the presence of a child's impairment and self-rated health assessment, the children were also asked "Do you have an illness or impairment?" and the parents were asked "Does your child have an illness or impairment?". The results of our study show that in all cases statistically significant correlations were found between the self-rated health assessment and the presence of impairment or illness in the child. It occurs most strongly $(V=.367)$ where the child's self-rated health is assumed as poor by parents as well. This can be explained by the fact that relatively few subjects fall into the category of poor-poor $(n=68)$. The lowest value of Cramer's $V$ $(V=.21)$ is when the self-rated health assessment of both children and parents is good. However, this can still be considered a strong association (Akoglu, 2018).

HRQoL assessment is correlated to the child's gender. When children's self-rated health report is poor, girl's self-assessments are very similar to those of their parent's proxy-reports, while boy's assessments are only moderately similar. When children's assessments of their self-rated health are good, boy's assessments are more strongly related to their parent's reports than in the case of the girls (see Figure 1). Gender does not play a role in the congruence of assessments when children's and parents' reports of self-rated health overlap (good-good, poor-poor).

\section{Figure 1}

Correlations Between Parent's and Children's Self-Rated Health Assessment and Children's Gender

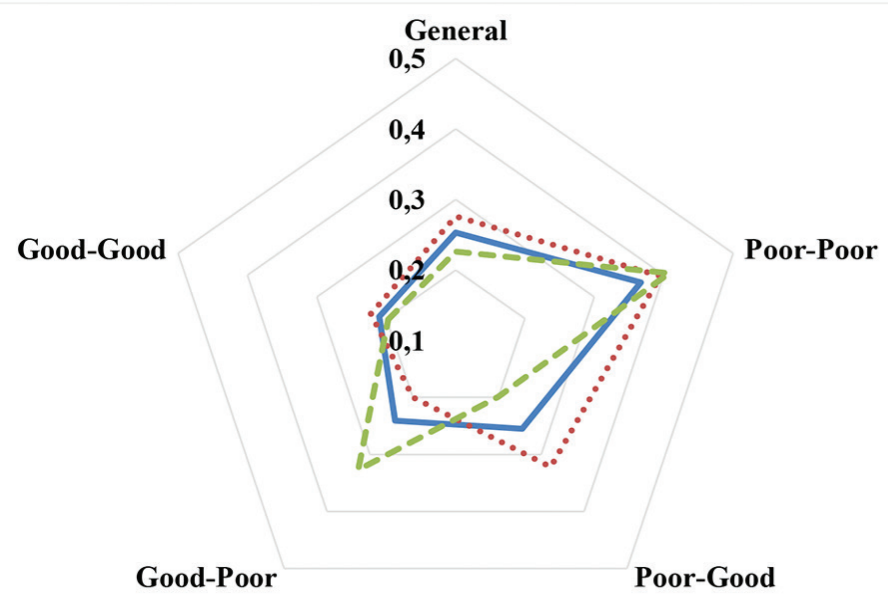


HRQoL assessment is closely correlated to the age of the children. The HRQoL assessments of parents and children coincide the least in the group of children aged 7-11 (see Figure 2). This is especially true where children's self-rated health assessment is poor, where the correlation is close to zero. Attention should also be paid to the group of children aged 12-15 years of age, where in the case of poor-poor assessment of self-rated health the correlation between parent's proxy and children's self-reports is particularly strong $(V=.509)$. In the group of older children (16-18 years old) the subgroup poor-good could be distinguished, with assessments about health being similar in 66 per cent of cases $(V=.378)$. Age does not matter for agreement in parents' and children/adolescent's reports where children's self-reports and parent's proxy-reports assess the child's self-rated health similarly (i.e., good-good).

\section{Figure 2}

Correlations Between Parent's and Children's Self-Rated Health Assessment and Children's Age
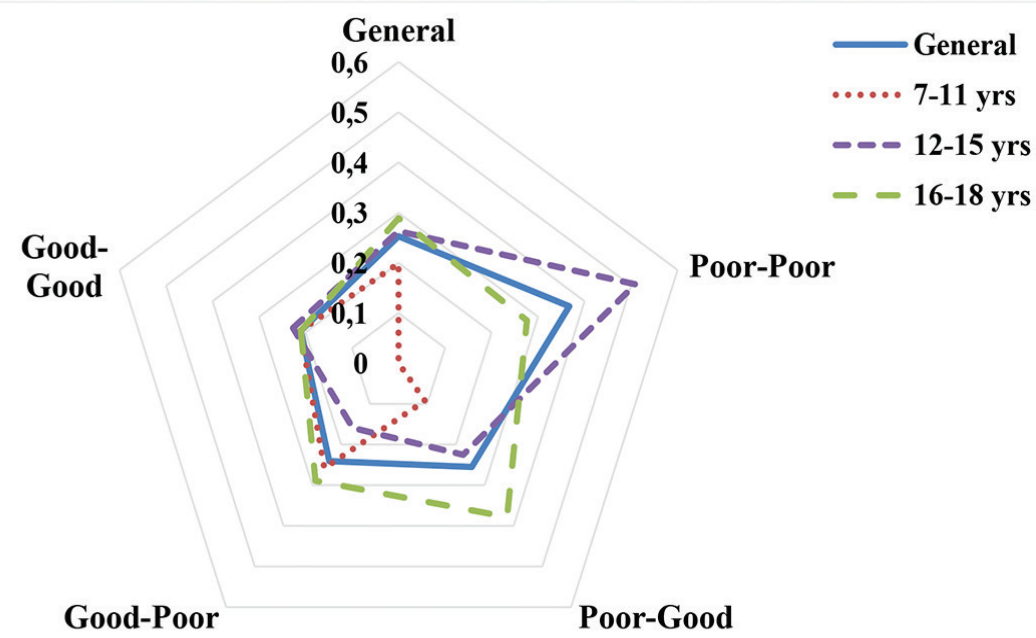

When evaluating the differences in children's and parents' reports in different dimensions, the Mann-Whitney $U$ test was used. The statistically significant differences are presented in Table 2 . 


\section{Table 2}

Statistically Significant Differences in the Assessment of Children-Parent's Evaluations Across Different Dimensions

HRQoL dimensions

Self-rated health (children-parents)

General Poor-Poor Poor-Good Good-Poor Good-Good

Physical activity

Family

Social and emotional well-being Independence and friendship

School environment and relationship

$\sqrt{ }$

$\sqrt{ }$

$\sqrt{ }$

$\sqrt{ }$
$\sqrt{ }$

$\sqrt{ }$

\section{$\sqrt{10}$}

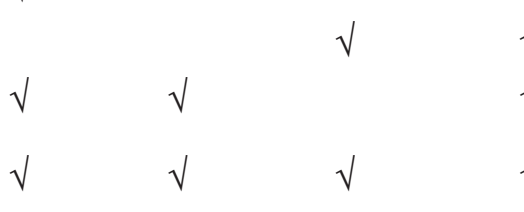

School environment and relationship is the only dimension which has statistically significant differences in all children/adolescent self-reported and parent proxy-reported self-rated health assessment categories. At the same time, it is the dimension with the largest gap between parent's and children's assessments (see Figure 3). The largest gap of assessment is observed where children/adolescents and parents report the child's self-rated health as good, while the smallest gap occurs when children report self-rated health as poor and parents assume it to be good.

\section{Figure 3}

Parent's and Children's School Environment and Relationship Dimension Evaluations According to Self-Rated Health Assessment

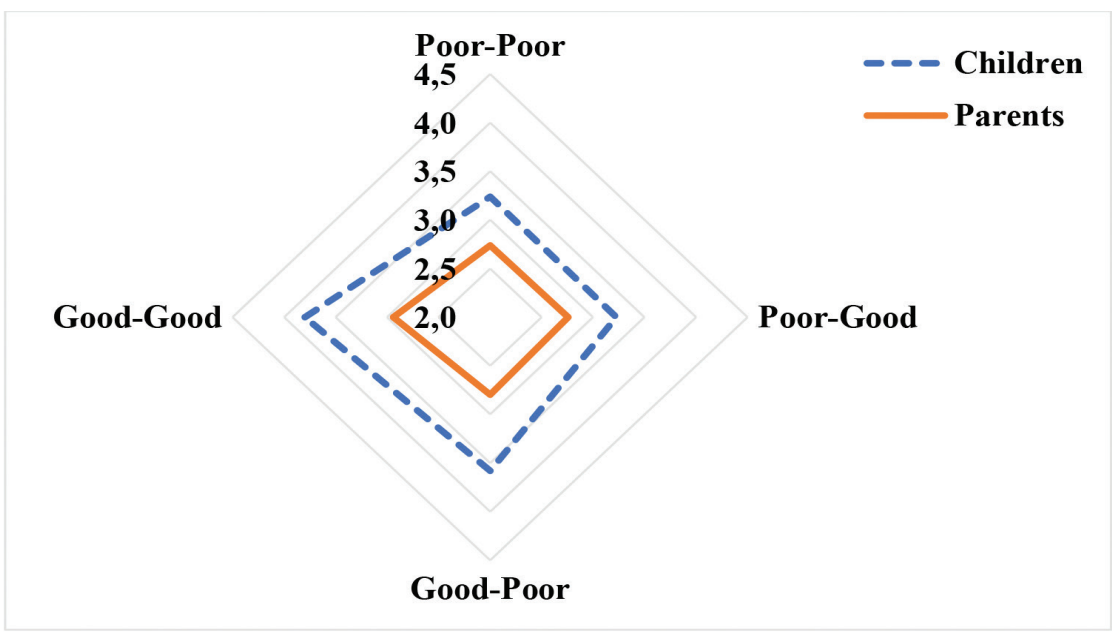


The social and emotional well-being dimension is characterized by the smallest gap between children's and parent's assessments, and statistically significant indicators are in the following two categories of self-rated health: good-poor and good-good. This leads to the conclusion that the strongest factor is good children's /adolescent's self-rated health assessment (see Figure 4).

\section{Figure 4}

Parent's and Children's Social and Emotional Well-Being Dimension Evaluations According to Self-Rated Health Assessment

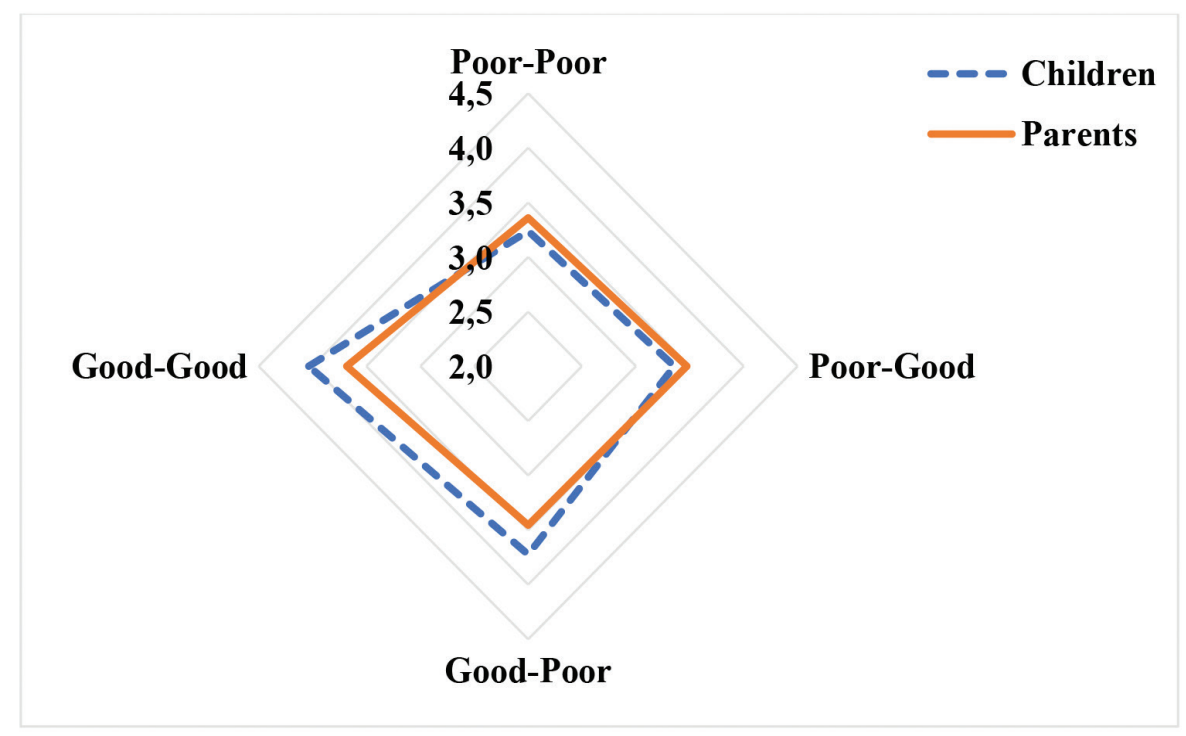

To find out if parental HRQoL assessment is correlated to whether children and parents talk about health, an additional question was asked of the families. The children/ adolescents were asked "Do you talk to your parents about your health?", while parents were asked "Do you talk to your child about his or her health? ". Statistically significant differences between those talking about health were obtained in the categories of poorpoor and good-poor in relation to children/adolescent's self-rated and parent's assumed health assessment respectively. This leads to the assumption that children and parents are inspired to talk about health when parents assume their child's self-rated health as poor (see Figure 5). 


\section{Figure 5}

Percentage of Parent's and Children's Communication About Health Depending on SelfRated Health Assessment

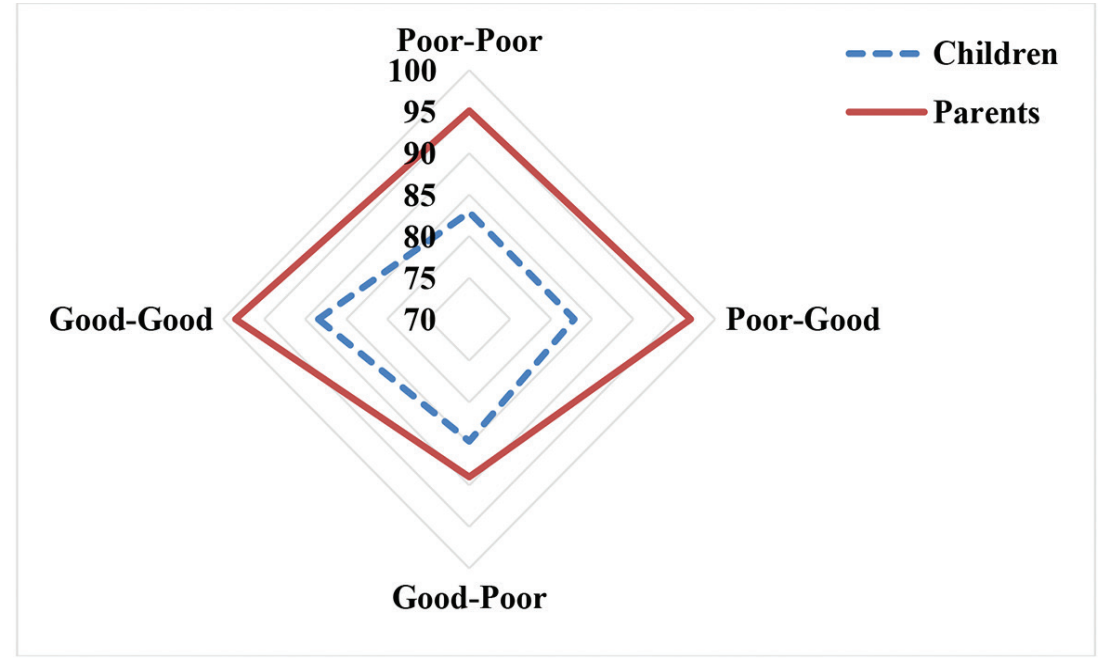

\section{Discussion}

A systematic review of research (Eiser \& Morse, 2001) shows that parents' and children/ adolescent's assessments overlap more often in observable physical domains (e.g. physical activity) and overlap less often in less observable domains (e.g. emotional functioning). Moreover, research often relates this to a child's age and gender factors. In addition, the results of our research allow linking them with the child's self-rated health assessment. In our study, the assessments between children/adolescents and parents in the case of the dimensions of physical activity and social and emotional well-being differs statistically significantly when the children/adolescent's self-rated health assessment is good (see Table 2). Furthermore, our study results demonstrated that parents underestimate health in three dimensions (i.e. social and emotional well-being, physical activity, school environment and relationship) and overestimate it in two dimensions (family, independence and friendship) compared to their children/adolescents. It is worth noting that parent's higher assessment of the family dimension is associated in a statistically significant way with assumed poor assessment of their child's self-reported health. Meanwhile, parental over-estimation due to a child's independence and friendship dimension is statistically significantly associated mainly with assumed good assessment of their child's self-rated health. However, our study does not help to answer the question posed by Upton and colleagues (2008), whether agreement is better for some measures than for others. 
In our study, the biggest discrepancy between parent's and children/adolescent's HRQoL assessments is in the school environment and relationship dimension, where statistically significant differences were observed in all the categories of self-rated health assessment reported by children and assumed by parents. So far, this large difference can be explained by the insights of Havermans and colleagues (2006), that possibly parents lack information about their children's situation at school. Also, we agree with Upton et al. (2008) assertion that differences might occur because parents will vary in their awareness, sensitivity, and tolerance of their children's health concerns. Differently than in the previous studies, in our study the smallest gap between parent's and children's HRQoL assessments is in the social and emotional well-being dimension and this is related to a child's self-rated health assessment being good.

Our study results show that the assessment of HRQoL between parents and children is most weakly correlated in the youngest group of children aged 7-11. In this sense, they are analogous to other studies which consider that younger children find it more difficult to express their emotional needs to their parents than school-aged children, leading to a greater disparity of their and their parent's answers (Gothwal et al., 2018). Longitudinal studies with a follow-up after 3 years (Rajmil et al., 2013) show positive changes towards more agreement between parents and children. The long follow-up period gave evidence that children's age has a positive impact on better parent's and children's agreements.

Our study data reasonably complement the field of similar research, but at the same time add a new dimension. This study suggests that the full version of the KIDSCREEN-52 questionnaire can be analyzed as a five-dimensional model. We believe that this can bring new insights into the dyadic health-related quality of life monitoring of children/ adolescents and parents reports.

Our study focuses on psychometric characteristics and did not aim to identify the meaning of socio-cultural factors in analyzing differences in health-related quality of life assessments between children and parents. However, we recognize it as an important variable, but it should be the subject of a separate study in the future. In our study, we were guided by the research which shows that the KIDCSREEN-52 instrument has been found to have excellent cross-cultural comparative validity (Haraldstad et al., 2011; Ravens-Sieberer et al., 2014).

\section{Conclusions}

The current study showed that Lithuanian children and their parents have significantly different perspectives on the child/adolescent's satisfaction with their quality of life. It confirms the notion that parent reports can never provide a good substitute for the child's own subjective experiences. Moreover, our study supports the reasonable use 
of the Lithuanian version of the KIDSCREEN-52 questionnaire as a reliable measure which is consistent with the original English version.

The results of our study suggest that HRQoL assessment by children and parents is significantly related to the child's health. The child's self-rated health assessment and that assumed by parents are closely related to whether the child has an illness, especially when both children/adolescents and parents report a poor assessment of the child's self-rated health. However, the opinions of children and parents differ not only due to the child's self-rated health assessment, but also due to impairment or illness. In only 58 per cent of cases do children's and parent's assessments match in saying that the child does not have an illness. Meanwhile, 29 per cent of the parents claim a child has an illness, while children claim that they do not have one. Although the results of previous studies show that HRQoL assessments of children and parents are more likely to coincide when a child/ adolescent has an illness, our study found that only 9 per cent of children/adolescents and parents agreed that the child has an illness. Hence, that trend and analysis can only be applied to the general population in a very small number of cases. From our point of view, HRQL should encompass illness integrated with self-rated health assessment.

The overlap between parent's and children's HRQoL assessments is related to mutually poor self-rated health assessment by both parents and children, to children being older and being female. Differences in parents and children/adolescent's HRQoL assessment are related to a child's/adolescent's self-rated health assessment as being good, irrespective of children's age. The biggest differences in children's and parents' assessments are in the school environment and relationship dimension, where children's and parent's assessments of a child's self-rated health are good. The smallest gap between children's/adolescent's and parent's reports occurs in the dimension of social and emotional well-being, when children report a good self-rated health assessment. This suggests that good self-rated health is a very broad concept that requires a separate conceptual focus for analysis that would undoubtedly serve the systematic monitoring of children's quality of life factors.

\section{References}

Akoglu, H. (2018). User's guide to correlation coefficients. Turkish Journal of Emergency Medicine, 18(1), 91-93. https://doi.org/10.1016/j.tjem.2018.08.001

Bombak, A. E. (2013). Self-rated health and public health: a critical perspective. Frontiers in Public Health, 1, 15. https://doi.org/10.3389/fpubh.2013.00015

Breidablik, H., Meland, E., \& Lydersen, S. (2009). Self-rated health during adolescence: stability and predictors of change (Young-HUNT study, Norway). European Journal of Public Health, 19(1), 73-78. https://doi.org/10.1093/eurpub/ckn111 
Cremeens, J., Eiser, C., \& Blades, M. (2006). Characteristics of health-related measures for children aged three to eight years: a review of the literature. Quality of Life Research, 15(4), 739-754. https://doi.org/10.1007/s11136-005-4184-x

Davis, E., Nicolas, C., Waters, E., Cook, K., Gibbs, L., Gosch, A., \& Ravens-Sieberer, U. (2007). Parent-proxy and child self-reported health-related quality of life: using qualitative methods to explain the discordance. Quality of Life Research, 16(5), 863-871. doi:10.1007/s11136-007-9187-3

Dey, M., Landolt, M. A., \& Mohler-Kuo, M. (2013). Assessing parent-child agreement in healthrelated quality of life among three health status groups. Social Psychiatry and Psychiatric Epidemiology, 48(3), 503-511. https://doi.org/10.1007/s00127-012-0556-Z

Eiser, C., \& Morse, R. (2001). Can parents rate their child's health-related quality of life? Results of a systematic review. Quality ofLife Research, 10 (4),347-357.https://doi.org/10.1023/A:1012253723272

Falconer, J., \& Quesnel-Vallée, A. (2017). Pathway from poor self-rated health to mortality: explanatory power of disease diagnosis. Social Science \& Medicine, 190, 227-236. doi:10.1016/j. socscimed.2017.08.008

Grubliauskienė, J. (2019). Edukacinè šeimos dimensija su sveikata susijusios vaikų gyvenimo kokybès vertinimo kontekste [daktaro disertacija]. Klaipèdos universiteto leidykla.

Gothwal, V. K., Bharani, S., \& Mandal, A. K. (2018). Parent-child agreement on health-related quality of life in congenital glaucoma. Trans Vis Sci Tech, 7(4):15, 1-13. https://doi.org/10.1167/ $\underline{\text { tvst.7.4.15 }}$

Haraldstad, K., Christophersen, K. A., Eide, H., Nativg, G. K., Helseth, S., \& KIDSCREEN Group Europe (2011). Health related quality of life in children and adolescents: reliability and validity of the Norwegian version of KIDSCREEN-52 questionnaire, a cross sectional study. International Journal of Nursing Studies, 48(5), 573-581. https://doi.org/10.1016/j. ijnurstu.2010.10.001

Havermans, T., Vreys, M., Proesmans, M., \& De Boeck, C. (2006). Assessment of agreement between parents and children on health-related quality of life in children with cystic fibrosis. Child: Care, Health and Development, 32(1), 1-7. https://doi.org/10.1111/j.13652214.2006.00564.X

Klassen, A. F., Miller, A., \& Fine, S. (2006). Agreement between parent and child report of quality of life in children with attention-deficit/hyperactivity disorder. Child: care, health and development, 32(4), 397-406. https://doi.org/10.1111/j.1365-2214.2006.00609.x

Knighting, K., Rowa-Dewar, N., Malcolm, C., Kearney, N., \& Gibson, F. (2011). Children's understanding of cancer and views on health-related behavior: a 'draw and write' study. Child: Care, Health and Development, 37(2), 289-299. https://doi.org/10.1111/j.1365-2214.2010.01138.x

Kostmann, E., \& Nilsson, L. (2012). Children's Perspectives on Health: What Makes Children Feel Good According to Themselves? International Journal of Education, 4 (1), 1-11. http:// www.macrothink.org/journal/index.php/ije/article/view/914

Matza, L. S., Swensen, A. R., Flood, E. M., Secnik, K., \& Leidy, N. K. (2004). Assessment of healthrelated quality of life in children: a review of conceptual, methodological, and regulatory issues. Value in Health, 7(1), 79-92. doi:10.1111/j.1524-4733.2004.71273.x 
Qadeer, R. A., \& Ferro, M. A. (2018). Child-parent agreement on health-related quality of life in children with newly diagnosed chronic health conditions: a longitudinal study. International Journal of Adolescence and Youth, 23(1), 99-108. https://doi.org/10.1080/02673843.2017.12 97242

Page, R. M., Simonek, J., Ihász, F., Hantiu, I., Uvacsek, M., Kalabiska, I., \& Klarova, R. (2009). Selfrated health, psychosocial functioning, and other dimensions of adolescent health in Central and Eastern European adolescents. The European Journal of Psychiatry, 23, 101-114. https:// doi.org/10.4321/S0213-61632009000200004

Rajmil, L., López, A. R., López-Aguilà, S., \& Alonso, J. (2013). Parent-child agreement on healthrelated quality of life (HRQOL): a longitudinal study. Health and Quality of Life Outcomes, 11, 101. https://doi.org/10.1186/1477-7525-11-101

Ravens-Sieberer, U., Auquier, P., Erhart, M., Gosch, A., Rajmil, L., Bruil, J., et al. (2007). The KIDSCREEN-27 quality of life measure for children and adolescents: psychometric results from a cross-cultural survey in 13 European countries. Quality of Life Research, 16, 1347-1356. https://doi.org/10.1007/s11136-007-9240-2

Ravens-Sieberer, U., Gosch, A., Erhart, M., et al., (2006). The KIDSCREEN questionnaires Quality of life questionnaires for children and adolescents. Handbook. The European KIDSCREEN group. Pabst Science Publishers.

Ravens-Sieberer, U., Herdman, M., Devine, J., Otto, C., Bullinger, M., Rose, M., \& Klasen, F. (2014). The European KIDSCREEN approach to measure quality of life and well-being in children: development, current application, and future advances. Quality of Life Research, 23, 791-803. https://doi.org/10.1007/s11136-013-0428-3

Rezende, B. A., Lemos S. M. A., \& Medeiros A. M. (2017). Quality of life and health selfperception in children with poor school performance. Revista Paulista de Pediatria, 35(4), 415-421. DOI: 10.1590/1984-0462/:2017;35;4;00009

Upton P., Lawford J., \& Eiser C. (2008). Parent-child agreement across child health-related quality of life instruments: a review of the literature. Quality of Life Research, 17(6), 895-913. https:// doi.org/10.1007/s11136-008-9350-5

Varni, J. W., Seid, M., Smith Knight, T., Burwinkle, T., Brown, J., \& Szer, I. S. (2002). The PedsQLTM in pediatric rheumatology. Reliability, validity, and responsiveness of the pediatric quality of life InventoryTM generic core scales and rheumatology module. Arthritis and Rheumatism, 46(3), 714-725. https://doi.org/10.1002/art.10095 


\title{
Vaikų ir tèvų su sveikata susijusios gyvenimo kokybės vertinimo skirtumų diadose monitoringas
}

\author{
Rita Vaičekauskaite் ${ }^{1}$, Jūratė Grubliauskienè ${ }^{2}$, Jurgita Babarskiené $\dot{3}^{3}$, Ričardas Krikštolaitis ${ }^{4}$
}

1 Klaipėdos universitetas, Sveikatos mokslų fakultetas, Herkaus Manto g. 84, 92294 Klaipèda, Lietuva, rita.vaicekauskaite@ku.lt

2 Klaipėdos universitetas, Sveikatos mokslų fakultetas, Herkaus Manto g. 84, 92294 Klaipėda, Lietuva, jurate.grubliauskiene@ku.lt

3 LCC Tarptautinis universitetas, Psichologijos katedra, Kretingos g. 36, 92307 Klaipeda, Lietuva, jbabarskiene@lcc.lt

4 Vytauto Didžiojo universitetas, Matematikos ir statistikos katedra, Vileikos 8, 44404 Kaunas, Lietuva, ricardas.krikstolaitis@vdu.lt

\section{Santrauka}

Su vaikų sveikata susijusios gyvenimo kokybės tyrimai neapsiriboja tėvų vertinimais, todèl vis dažniau anketas pildo ir vaikai. Vis dèlto susiduriama su problema, kad vaikai ir tèvai skirtingai vertina gyvenimo kokybę. Buvo manoma, kad skirtumus lemia skirtingos anketos. Sukūrus KIDSCREEN klausimyną, kuris turi identiškas versijas vaikams ir tėvams, vis tiek vertinimo skirtumai išlieka pakankamai ryškūs.

Tyrime dalyvavo 1564 vaikai, paaugliai ir tèvai, kurie pildè KIDSCREEN-52 klausimyno lietuvišką validuotą versiją. Tyrimo duomenys rodo, kad daugiausia tèvų ir vaikų gyvenimo kokybès dimensijų vertinimai išsiskiria, kai vaikų ir tėvų subjektyvus sveikatos vertinimas yra geras, o sutampa, kai subjektyvus sveikatos vertinimas yra blogas. Vis delto tik 9 procentai vaikų ir tėvų sutaria dèl blogo subjektyvios sveikatos vertinimo. Nors 58 procentai vaikų ir tėvų sutaria dèl to, kad vaiko sveikata gera, tačiau geras sveikatos vertinimas nebūtinai reiškia vienodai gerą vaikų ir tėvų gyvenimo kokybės vertinimą. Trūkstant konceptualumo, negalima pasakyti, kad vieni skirtumai yra geri arba blogi. Tyrimo metu subjektyvaus sveikatos vertinimo pagrindu išskirtos keturios vaikų ir tèvų diadų kategorijos, kurios tolesniuose tyrimuose igalina modeliuoti konkrečias su sveikata susijusios vaikų gyvenimo kokybės gerinimo edukacines strategijas.

Esminiai žodžiai: subjektyvus sveikatos vertinimas, su sveikata susijusi gyvenimo kokybe, vaikai ir paaugliai, diadinis vertinimas.

Gauta 20210329 / Received 29032021

Priimta 20210611 / Accepted 11062021 